\title{
Teaching Culture Explicitly through Literature to EFL Learners
}

\author{
Mehrdad Rezaee \\ Department of Foreign Languages, Central Tehran Branch, Islamic Azad University, Tehran, Iran \\ Email: mehr351@yahoo.com \\ Majid Farahian \\ Department of Foreign Languages, Kermanshah Branch, Islamic Azad University, Kermanshah, Iran \\ Email: majid_fa53@yahoo.com
}

\begin{abstract}
Teachers/learners of foreign language (FL) have always faced a demanding task of learning/teaching L2/FL culture and despite the fact that diverse methods have been proposed to teach FL/L2 culture in language classes, the difficulties have not been completely removed. One of the possible ways would be using literary works to teach the cultural issues of the $L 2$ to the learners. The purpose of this paper is to discuss the importance and the effect of using literature to teach $\mathrm{L} 2$ culture in the English language classes. To this aim, 40 upper-intermediate English language students were randomly selected and also randomly assigned to experimental and control groups (20 students for each group). Both groups were given a pre-test of some 20 L2 cultural questions. As the treatment, the experimental group was given a fifteen-session teaching of literary texts specifically selected for their cultural points together with a thorough explanation of those points while the control group went through a normal reading class with ordinary texts. Finally, a post-test was administered to both groups. The results showed a significant difference between the experimental and control groups. The delayed post-test administered after two weeks confirmed the results, too. The findings may contribute to explicit teaching of culture through literature in L2/FL classrooms.
\end{abstract}

\section{Index Terms - teaching culture, literature, EFL learners}

Anyone who has ever tried to learn/acquire a second/foreign language knows that it is a very hard, demanding, and even for some people, a tiring task. In fact, "learning/acquisition of a second/foreign language is comprised of different factors many of which can affect the way a person learns/acquires it. Some of these factors are cognitive, others are affective, still others are social, some others are biological and the rest are personal" (Brown, 2007, pp. 2-3). Previously, it was believed that to "learn a second language successfully, one has only to get the linguistic competence in that language" (Brown, 2000, p. 247). In other words, when someone has a good listening and pronunciation, a sound knowledge of vocabulary together with a good mastery over meaning of sentences and structures, he has the linguistic competence. However, nowadays it is believed that although it is necessary to have a grammatical competence in a language, it is by no means sufficient. In other words, besides the knowledge of the four issues mentioned above, one needs other aspects of language to be able to claim mastery over that language. Hymes (1972) introduced the issue of communicative competence which was composed of different types of competencies such as discourse, pragmatic, sociolinguistic and also strategic competences. However, newer dimensions that some other scholars (e.g., Bachman, 1990) have assumed for communicative competence have become broader and have considered cultural issues a subcategory of competence as well. Nevertheless, scholars (Byram, 2000) have introduced even a more recent category called intercultural competence, which according to him has five elements. Two of these elements are related to Attitudes and Knowledge which are as follows:

$\diamond$ Attitudes: curiosity and openness, readiness to suspend disbelief about other cultures and belief about one's own.

$\diamond$ Knowledge: of social groups and their products and practices in one's own and in one's interlocutor's country, and of the general processes of societal and individual interaction. (p. 9)

Then he states that the other three are related to Skills and Critical cultural awareness/political education and are as follows: "Skills of interpreting and relating; Skills of discovery and interaction; and Critical cultural awareness/political education" (Byram, 2000, p. 9).

Too, he states that "Intercultural competence together with learners' linguistic, sociolinguistic and discourse competence form intercultural communicative competence (ICC). Learners with an ICC can link the knowledge of the other culture to their language competence through their ability to use language appropriately" (Byram, 2000, p. 10).

In the meantime, some researchers emphasize some of the important roles of culture like its necessity in language classes. Along the same line, Chan and Herrero (2010) clearly argue that, "Literacy pedagogy should be linked with the changing social environment calling for a much broader view of literacy than portrayed by traditional language-based approaches" (p. 8). At the same time, they state that "We must recognise the increasing cultural and linguistic diversity, proposing through the use of multiliteracies a fairer social and cultural participation" (p. 8). 
With such an emphasis on teaching culture, it gets clear that there are different ways to teach culture to language students. Of course, there are situations in which the students, especially second language learners, have access to the target culture and can learn it easily, but in other cases, the students can't have access to the L2/FL culture and so, they will have problem with them. In the latter condition, students must be taught culture, but how.

Different ways and methods have been proposed for teaching culture in language classes. For example, Jones (2011) proposes ways such as "'Using role play', 'developing a mental image of the target culture', 'Celebrating a holiday or festival of the target culture', or 'Teaching culture through nonverbal communication"” (p. 1). However, Chastain (1988) talks about two general ways of presenting L2 culture to language students. The first way is "In Class" which is divided into 'Culture Capsule', 'Culture Cluster', and 'Minidramas' or 'Miniskits', 'The Micrologue', and 'Cultoon', while the second way according to Chastain in called "Out Of Class" which is divided into 'Pen Pals', 'Special Programs and events', 'Community Resources', 'Travelogue Films', 'Summer Camps' and so on. (p. 130) Of course, each of the above-mentioned ways has some demerits which make its use very difficult at some points. But, one of the best ways to teach L2 culture is through using L2 literature. It should be mentioned though, that research in using literature to teach L2 culture has focused on just one aspect of literature and that is, "Using L2 folktales and short stories" to teach L2 culture. In fact, according to researchers, using folktales can be a magic in teaching L2 culture and language. (Price, 2001) But what is Folktale and how can it be defined? According to Baynham (1986),

Folk stories have long been part of the repertoire of the language teachers, and many simplified reading series recount stories of Mullah Nasreddin and other archetypal folk figures. The themes often have a universal appeal and are frequently very widely distributed across cultures, so they make ideal reading in the early stages of the languagelearning process (p. 113)

However, other studies have come to the conclusion that using folktales in teaching L2 culture was not so much successful and useful as expected, though it was better than the methods mentioned by Chastain (1988) and Jones (2011). In this regard, Baynham (1986) talks about one of the difficulties in working on folk stories with a group of students. According to him, when the topic is raised out of context in the ESL classroom, the response may well be 'oh, I don't know any' or other similar responses. Another problem was that the stories were used mostly for the purpose of teaching 'Spelling' 'Grammar', 'Vocabulary', and 'Punctuation'. Culture was the last issue to be considered. Nevertheless, it must be mentioned that except the papers mentioned above (about folktales), the number of studies done on using folktales to teach L2 culture is very few and as mentioned above, almost all of them have focused on using folktales to teach other aspects of language in the classroom rather than using it primarily to teach L2 culture. For this very reason, the present authors have tried to do this study. Thus, the following research question came into their minds:

What is the effect of using L2 literature on teaching L2 culture explicitly to EFL learners?

Based on the above research question, a null hypothesis can be given as "Using L2 literature has no effect on teaching L2 culture explicitly to EFL learners".

\section{METHOD}

\section{A. Participants}

40 upper-intermediate English language students (in two experimental and control groups of 20) were selected randomly through simple randomization from among 89 upper-intermediate students at the author's own language institute. (It is worth mentioning that the upper-intermediate level in the mentioned institute has three grades of $1,2, \&$ 3 ; however, all of the 89 students from whom 40 subjects were selected, were either upper-intermediate 2 or upperintermediate 3). Since all of the 89 students were almost in the same grade level (based on their final scores of the previous semester), they were paired on the basis of that final score and so, no general English test was used to select the subjects and only a simple sampling was used for that purpose. The subjects were randomly assigned to control and experimental groups. The subjects in both groups had an age range of 23 to 27 years old, i.e., there was only an age range of four years. All of the subjects were female and BS students at the university in different fields (Other than English language).

\section{B. Tasks and Data Collection Procedure}

Since a pre-test and a post-test were going to be used in this research, at the beginning of the study, as a pre-test, both the control and the experimental groups were given a pre-test of some 20 L2 cultural questions randomly selected from some short stories. Two university EFL professors who had lived in English speaking countries for more than 6 years were asked to score the pre-test. To ensure the reliability of the agreement between the raters, the correlation between the raters was calculated and determined to be adequate. Then, the experimental group went through 15 sessions of instruction in which they were taught some 20 short stories and folktales. The literary works were selected randomly based on the cultural issues they had. The procedure to teach short stories and the cultural content for the experimental group was as follows. First of all, the students who had been asked to read the short stories as their homework at home, discussed the concept of the short stories and folktales in groups and if there was any misunderstanding regarding the texts, the instructor and students contributed their own ideas. Then, they were asked to find specific cultural issues introduced in the folktales, and short stories. In the next step, the students were required to compare the cultural point(s) 
with that (those) of their own (Persian culture) and discuss their ideas with the rest of the class. Finally, the instructor explained explicitly the cultural point(s) and gave the background of the related issue. As to the control group, they attended a reading course in which the same reading passages were taught based on the conventional techniques to teach literary texts. The conventional method of teaching short stories in literature courses consisted of instructors giving lectures and students receiving the information and the interpretation of the story. There was no implicit or explicit mentioning of cultural issues for this group. After 15 sessions of instruction for both groups, a post-test was administered with some 20 questions related to the American cultural issues which had appeared in the folktales and literary works taught throughout the fifteen-session course. These were the same questions used in the pre-test. Each question had 1 score, the total of which would be 20 . However, in cases in which students could point at a specific piece of information, they could get $.25, .5$ or sometimes .75 because they knew some parts of the answer to the question. Like the procedure in the pre-test, to ensure the inter-rater reliability, the correlation between the scores of the raters was determined. To get more confident that the subjects (especially the experimental group) did not memorize the cultural issues that were presented in the short stories and folk-tales, 20 different and additional American culturalrelated questions were administered to both the experimental and the control groups in the same exam session and scored in the same manner. To make even more confident about the results and to ensure that the results were not due to memorizing the cultural issues merely for the purpose of the Post-test, a delayed Post-test was administered for both the Control and Experimental Groups two weeks after the Post-test to be sure that there was real gaining in the treatment for the Experimental Group and in fact to make confident that the treatment was really effective. Then, there was a comparison between the Control and the Experimental Groups regarding the descriptive statistics and also a paired t-test was administered based on the results.

\section{Data Analysis Procedures}

To study the differences between the two groups, the researcher used different statistical instruments such as mean, mode, variance, SD, and three paired t-tests (between group t-tests) with .05 Level of Significance.

\section{RESULTS}

Looking at Table 1 (Descriptive statistics of the pre-test taken by both control and experimental groups), we see that there is no significant difference between the two groups regarding their mean and Standard Deviation. As we see, the SD of Control Group Pre-test is .48310 and the SD of Experimental Pre-test is .38453. The range in Pre-test Control Group is 1.75 and it is 1.5 for Pre-test Experimental Group (The Mean of Control Group Pre-test is 1.6375 and the Mean of Experimental Pre-test is 1.5125). However, looking at Table 2., we can see that the SD in Post-test Control Group is .31519 while the SD of Post-test Experimental Group is .63037 (Almost double that of the Post-test Control Group SD). Too, the Mean in both groups is very much different. In other words, the Mean of Post-test Control Group is 1.6750 but the Mean of the Post-test Experimental Group is 8.6000.

TABLE 1.

DESCRIPTIVE STATISTICS OF CONTROL/EXPERIMENTAL GROUPS PRE-TEST

\begin{tabular}{|l|l|l|l|l|l|l|l|l|}
\hline & $\mathrm{N}$ & Range & Minimum & Maximum & Mean & Std. Deviation & Variance \\
\cline { 2 - 8 } & Statistic & Statistic & Statistic & Statistic & Statistic & Std. Error & Statistic & Statistic \\
\hline PreCGroup & 20 & 1.75 & .75 & 2.50 & 1.6375 & .10803 & .48310 & .233 \\
PreEGroup & 20 & 1.50 & .50 & 2.00 & 1.5125 & .08598 & .38453 \\
\hline
\end{tabular}

TABLE 2.

DESCRIPTIVE STATISTICS OF CONTROL/EXPERIMENTAL GROUPS POST-TEST

\begin{tabular}{|l|l|l|l|l|l|l|l|l|}
\hline & $\mathrm{N}$ & Range & Minimum & Maximum & Mean & Std. Deviation & Variance \\
\cline { 2 - 9 } & Statistic & Statistic & Statistic & Statistic & Statistic & Std. Error & Statistic & Statistic \\
\hline PoCGroup & 20 & 1.00 & 1.25 & 2.25 & 1.6750 & .07048 & .31519 & .099 \\
PoEGroup & 20 & 2.00 & 7.50 & 9.50 & 8.6000 & .14096 & .63037 & .397 \\
\hline
\end{tabular}

Meanwhile, looking at Table 3., we see the results based on paired t-test which showed that there was no significant difference between the performance of subjects in the Pre-test Control Group and that of the Experimental Group. The T-Observed with 95\% Confidence interval of the differences with 19 degree of freedom was .990 which is by far lower than what it should be to show a meaningful difference between the performance of the Control and Experimental Groups. (To be meaningful, the amount of Observed T with 95\% Confidence interval of the differences with 19 degree 
of freedom must be at least 2.093). So, we can conclude that there was no significant difference between the two groups regarding their performance. In other words, there was no superiority of one group over the other. However, Table 4. (Paired t-test of Post-test Control/Experimental groups), shows a great difference between the performance of subjects in the two groups. This means that the amount of Observed T with 95\% Confidence interval of the differences with 19 degree of freedom was -51.911 which shows a significant difference between the two groups (The Experimental Group performed much better that the Control Group). In other words, the amount of Observed T shows that the Experimental group in the Pos-test Experimental Group could answer the cultural questions very well as they had learnt the American cultural points by attending the fifteen-session of classes in which the teacher analysed the L2 cultural issues. But this was not the case with the Post-test Control Group as they went through the ordinary reading classes in which ordinary texts were taught in a traditional manner. One point is also worth mentioning here and that is, in the "Tasks and data collection procedure" it was stated that, 10 different and additional American cultural-related questions were administered to both the experimental and the control groups in the same exam session to get more confident that the subjects (especially the experimental group) did not memorize the cultural issues that were presented in the short stories and folk-tales. The results revealed that still the experimental group was much better in their performance and this showed that they had not memorized the cultural issues as the questions were different from those taught in the classes and the latter set of questions were not among the materials used in the classes.

TABLE 3.

PAIRED T-TEST OF PRE-TEST CONTROL/EXPERIMENTAL GROUPS

\begin{tabular}{|c|c|c|c|c|c|c|c|c|}
\hline & \multicolumn{5}{|c|}{ Paired Differences } & \multirow[b]{3}{*}{$\mathrm{t}$} & \multirow[b]{3}{*}{$\mathrm{df}$} & \multirow{3}{*}{$\begin{array}{l}\text { Sig. (2- } \\
\text { tailed) }\end{array}$} \\
\hline & \multirow[b]{2}{*}{ Mean } & \multirow[b]{2}{*}{ Std. Dev. } & \multirow{2}{*}{$\begin{array}{l}\text { Std. Error } \\
\text { Mean }\end{array}$} & \multicolumn{2}{|c|}{$\begin{array}{l}95 \% \text { Confidence Interval of } \\
\text { the Difference }\end{array}$} & & & \\
\hline & & & & Lower & Upper & & & \\
\hline Pair 1 PreCGroup/PreEGroup & .12500 & .56487 & .12631 & -.13937 & .38937 & .990 & 19 & .335 \\
\hline
\end{tabular}

TABLE 4.

PAIRED T-TEST OF POST-TEST CONTROL/EXPERIMENTAL GROUPS

\begin{tabular}{|c|c|c|c|c|c|c|c|c|}
\hline & \multicolumn{5}{|c|}{ Paired Differences } & \multirow[b]{3}{*}{$\mathrm{t}$} & \multirow[b]{3}{*}{ df } & \multirow{3}{*}{$\begin{array}{l}\text { Sig. (2- } \\
\text { tailed) }\end{array}$} \\
\hline & \multirow[b]{2}{*}{ Mean } & \multirow[b]{2}{*}{ Std. Dev. } & \multirow{2}{*}{$\begin{array}{l}\text { Std. Error } \\
\text { Mean }\end{array}$} & \multicolumn{2}{|c|}{$\begin{array}{l}\text { 95\% Confidence Interval of the } \\
\text { Difference }\end{array}$} & & & \\
\hline & & & & Lower & Upper & & & \\
\hline Pair 1 PosCGroup/PosEGroup & -6.92500 & .59659 & .13340 & -7.20421 & -6.64579 & -51.911 & 19 & .000 \\
\hline
\end{tabular}

As mentioned in the "Tasks and Data Collection Procedure" section, to make more confident that the results gained after the treatment were really due to the treatment not other things such as memorization, a delayed Post-Test was administered in which both the Control and the Experimental Groups took the test for the third time with the results given in Tables 5 and 6 .

As we see in Table 5., there is still a great difference between the means of the Control and Experimental Groups in the Delayed Post Test (1.6875 vs. 7.9875). Meanwhile, the SD of the Control and Experimental Groups in the Delayed Post Test is by far different from each other (.40454 vs. 1.71961).

Meanwhile, regarding the paired t-test results gained for the Control/Experimental Groups' Delayed Post-Test (as shown in Table 6), we can see that still the amount of observed $t$ is -16.957 which means that still there is a significant difference between the two groups regarding their performance on the test results. In other words, after two weeks, still the Experimental Group did have a much higher performance than the Control Group in the test given after the treatment. So, we can be more confident that the results gained are due to the treatment.

TABLE 5.

DESCRIPTIVE STATISTICS OF CONTROL/EXPERIMENTAL GROUPS' DELAYED POST-TEST

\begin{tabular}{|l|l|l|l|l|l|l|l|l|}
\hline & $\mathrm{N}$ & Range & Minimum & Maximum & Mean & Std. Deviation & Variance \\
\cline { 2 - 9 } & Statistic & Statistic & Statistic & Statistic & Statistic & Std. Error & Statistic & Statistic \\
\hline DPosCGroup & 20 & 1.50 & 1.00 & 2.50 & 1.6875 & .09046 & .40454 & .164 \\
DPosEGroup & 20 & 8.25 & 1.25 & 9.50 & 7.9875 & .38452 & 1.71961 & 2.957 \\
Valid N (listwise) & 20 & & & & & & & \\
\hline
\end{tabular}

TABLE 6.

PAIRED T-TEST OF CONTROL/EXPERIMENTAL GROUPS’ DELAYED POST-TEST

\begin{tabular}{|c|c|c|c|c|c|c|c|c|}
\hline & \multicolumn{5}{|c|}{ Paired Differences } & \multirow[b]{3}{*}{$\mathrm{t}$} & \multirow[b]{3}{*}{$\mathrm{df}$} & \multirow{3}{*}{$\begin{array}{l}\text { Sig. }(2 \\
\text { tailed) }\end{array}$} \\
\hline & \multirow[b]{2}{*}{ Mean } & \multirow[b]{2}{*}{ Std. Dev. } & \multirow[b]{2}{*}{ Std. Error Mean } & \multicolumn{2}{|c|}{$\begin{array}{l}\text { 95\% Confidence Interval } \\
\text { of the Difference }\end{array}$} & & & \\
\hline & & & & Lower & Upper & & & \\
\hline Pair 1 DPosCGroup/DPosEGroup & -6.30000 & 1.66148 & .37152 & -7.07760 & -5.52240 & -16.957 & 19 & .000 \\
\hline
\end{tabular}

\section{DISCUSSION \& CONCLUSION}


Taking a second look at the results, we can see that before the treatment, both groups were almost the same and there was no significant difference in the performance of the two groups. But, after the treatment, there was a significant difference in their performance in that the Experimental Group had by far a better performance than the Control Group. This means that the treatment was significantly effective. However, we can have some implications by looking at the tables. The first implication can be gained by looking at Tables 1 and 3. The implication is that in our language classes, culture is taught very little (if done at all). Unfortunately, instead of teaching L2/FL culture, teachers try to teach other things such as grammar or writing. This can be due to teachers' lack of familiarity with the L2/FL cultural issues. Another implication from Table 1 is that students might have heard some cultural issues from here and there (because all of the scores of both Control and Experimental Groups were above zero). This means that they might have some ideas of those cultural issues, but these ideas are either partly correct or half-clear and half-vague. This shows that there are some ideas, and students are not completely blank about the cultural issues; however, the point is that we don't know where they have got those ideas. Still, an implication taken from Table 4 is that although the treatment was successful before the Post-test, none of the subjects could answer the Post-test questions 100\% correctly. Why? The reason can be due to the fact that learning L2 cultural issues is not a one-shot performance. In other words, one can't learn cultural issues by hearing or seeing them only once as some of them might be so strange that one may need to see or hear them several times in order to learn them or to keep them in mind. However, they were useful as they caused a drastic change in the scores of the Experimental Group.

Based on what was said above, one can state that language and culture are inseparable from each other and to learn a language well, one must try to learn the culture of that language as much as possible. So, without learning the L2 culture, it is almost impossible to get a sound knowledge of the second language. Too, different definitions of the word culture were presented from different scholars and it was pointed out that culture can mean different things to different scholars as some of them use it with small ' $c$ ' to refer to the behavioural patterns and the everyday lifestyles of people while others use it with capital ' $C$ ' to mean art, music, literature, politics, etc. Meanwhile, as it was said, though teaching culture is very much important, unfortunately so few teachers pay attention to this very important issue and instead, pay more attention to other aspects of language such as grammar and vocabulary and spend the class time mostly to those parts. This is because they don't know how to teach culture. Besides, it was stated that learning culture in conditions in which there is an opportunity for language learners to travel to the L2 countries is much more appropriate but not all learners have this opportunity. So, the best possible way would be using literature or literary works to teach the cultural issues of the L2 to the learners. However, it should be mentioned that using literature or literary works for the purpose of teaching culture and cultural issues must be done in an organized way and under complete supervision. Otherwise, there will be no proper result other than mere waste of time.

\section{ApPendix A SAmPle of Cultural Questions Asked in both Pre-test And Post-Test}

1. When is the Independence Day in America?

2. When is President's Day?

3. When is Halloween and what do American people do on that day?

4. Why do people hold Thanksgiving Day and what do they do in that day?

5. When is Mother's Day in America?

6. When is April Fool's Day?

7. What is Good Friday?

8. When is Holy Saturday and why is it called Holy?

9. What is Inauguration Day?

10. What is Ladies' Day and why is it significant?

11. When is Ester? What is so specific about that day?

\section{REFERENCES}

[1] Bachman, L. F. (1990). Fundamental Considerations in Language Testing. Oxford: Oxford University Press.

[2] Baynham, M. (1986). Bilingual folk stories in the ESL classroom. ELT Journal, 40(2), 113-120.

[3] Brown, H. D. (2000). Principles of language learning and teaching ( $4^{\text {th }}$ ed.). NY: Pearson Education.

[4] Brown, H. D. (2007). Principles of language learning and teaching $\left(5^{\text {th }}\right.$ ed.). NY: Pearson Education.

[5] Byram, M. (2000). Assessing intercultural competence in language teaching. Sprogforum, 6(18), 8-13.

[6] Chan, D., \& Herrero, C. (2010). Using film to teach languages. Retrieved July 28, 2011, from http://www.cornerhouse.org/media/Learn/General\%20docs/TeachersToolkit_Jun2010.pdf

[7] Chastain, K. (1988). Developing second language skills ( $3^{\text {rd }}$ ed.). New York: Harcourt Brace.

[8] Erkaya, O. R. (2005). Benefits of using short stories in the EFL context. Asian EFL Journal, 8. Retrieved March 11, 2011, from http://www.asian-efl-journal.com/pta_nov_ore.pdf

[9] Erkaya, O. R. (2011). Advantages of using translated stories from students' native language to teach EFL. The Journal of Language Teaching and Learning, 1(2), 57-66

[10] Hymes, D. (1972). On communicative competence. In J. B. Pride, \& J. Holmes (Eds.), Sociolinguistics (pp. 269-293). Harmondsworth: Penguin. 
[11] Jones, K. (2011). How to teach culture in an L2 classroom. Retrieved May, 7, 2011, from http://www.ehow.co.uk/how_7770595_teach-culture-12-classroom.html

[12] Price, P. (2001). The magic of folktale for teaching English and culture. The Journal of Imagination in Language Learning and Teaching, 6. Retrieved May 12, 2011, from www.njcu.edu/cill/vol6/price.html

[13] Ruhong, L. (2008). Why is it important to study culture? Retrieved June 9, 2011, from http://www.amityfoundation.org/page.php?page $=1438$

[14] Saluveer, E. (2004). Teaching culture in English classes. Unpublished master's thesis. Tartu: University of Tartu.

[15] Sell, J. P. A. (2005). Why teach literature in the foreign language classroom? Encuentro, 11. Retrieved May 14, 2011, from www.encuentrojournal.org/textos/11_Sell.pdf

[16] Valdes, G. M. (1986). The teaching of culture in the ESL and foreign language classes. Retrieved June25, 2011, from: http://www.eric.ed.gov/ERICDocs/data/ericdocs2sql/content_storage_01/0000019b/80/2e/19/8d.pdf

Mehrdad Rezaee is a lecturer in the Department of Foreign Languages, Central Tehran Branch, Islamic Azad University, Tehran, Iran and at the same time, he is studying for his Ph.D. (Applied Linguistics) in Islamic Azad University, Science and Research Branch, Tehran, Iran. He has been teaching all courses related to ELT in Associate Diploma and BA levels at Islamic Azad University, Tehran Central Branch.

Majid Farahian is a lecturer in the Department of Foreign Languages, Kermanshah Branch, Islamic Azad University, Kermanshah, Iran, and at the same time, he is studying for his Ph.D. (Applied Linguistics) in Islamic Azad University, Science and Research Branch, Tehran, Iran. He has been teaching all courses related to ELT in Associate Diploma and BA levels at Islamic Azad University, Kermanshah Branch. He has had different articles on Linguistics, Teaching, and Literature in different journals. 